\title{
Peculiarities of the Socio-Demographic «Portrait» of the People Searching for a Marriage Partner Online
}

\section{Особливості соціодемографічного «портрета» осіб, які шукають шлюбного партнера в інтернет-мережі}

\author{
Vitaliia Shebanova \\ Dr. in Psychology, Professor, Professor of the Department of \\ Practical Psychology, Kherson State University, Kherson (Ukraine) \\ ORCID ID: https://orcid.org/0000-0002-1658-4691 \\ Researcher ID: D-2740-2019 \\ E-mail: vitaliashebanova@gmail.com
}

\section{Віталія Шебанова}

Доктор психологічних наук, професор, професор кафедри практичної психології, Херсонський державний університет, м. Херсон (Україна)

\section{ABSTRACT}

The aim of the article is to find out the peculiarities of the socio-demographic "portrait» of the people who are searching for a marriage partner online.

Research methods and techniques are the methodological tools of the research which included the analysis and generalization of works devoted to the study of the virtual discourse of the people searching for a marriage partner online; content analysis of personal data in the context of identifying the peculiarities of language self-presentation of the users searching for a marriage partner online. Data collection for the empirical study was carried out on the site Love.ua.

Address for correspondence, e-mail: kpnu_lab_ps@ukr.net Copyright: (C) Shebanova Vitaliia

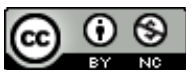
The article is licensed under CC BY-NC 4.0 International (https://creativecommons.org/licenses/by-nc/4.0/)

\section{(C) Shebanova Vitaliia}

DOI (article): https://doi.org/10.32626/2227-6246.2020-49.386-406 
The sample of the research consisted of 120 Internet pages on the dating site (50 female and 70 male profiles). All obtained empirical data were analyzed separately for the sample of men and the sample of women. The significance of the difference was calculated using Fisher's $\varphi$-test.

The results of the research made it possible to determine the peculiarities of the socio-demographic "portrait» of the people who are searching for a marriage partner online.

Conclusions. The identified gender characteristics in the answers to the questionnaires of a dating site reflect the real socio-demographic trends in Ukrainian society.

It was found that for most men, the situation of online dating is a continuation of a real life situation, expanding its capabilities. Women mostly turn to a dating site as an alternative (compensation) to a real life situation. Adolescents and young people use the site as a "training" platform, learning to flirt and trying different tactics of behavior towards people of the opposite sex.

It is investigated that when creating the self-presentation on a dating site, the author is limited by the framework of the template (questionnaire) that regulates communicative behavior, but he is given relative autonomy to create his own image. The users of a site usually avoid answering questions related to their social status, education and financial status. However, in the case of a serious attitude to acquaintance, this information is necessary, because it relates to the similarity of a social base of future partners.

Key words: Internet communication, linguistic self-presentation of a personality, analysis of personal data, online dating, partner search.

\section{Вступ}

Наприкінці XX ст. завдяки розвитку технологій з'явився новий спосіб комунікації - спілкування з віртуальним співрозмовником за допомогою електронних засобів. Інтернет надав змогу людині значно розширити межі спілкування, залучив особистість до процесу комунікації навіть тоді, коли у реальному житті у неї існують певні бар'єри для цього. У наш час для того, щоб познайомитися, знайти друга, чоловіка / дружину чи коханця, достатньо звернутися з відповідним запитом в інтернет-мережу, де існує значна кількість сервісів знайомств. Частина користувачів цих сервісів

(c) Shebanova Vitaliia

DOI (article): https://doi.org/10.32626/2227-6246.2020-49.386-406 
має серйозні наміри та дійсно бажає знайти собі партнера для тривалих стосунків.

Основна особливість віртуального спілкування - це можливість повного управління враженням про себе. Саме тому науковці підкреслюють першорядну важливість самопрезентації, самоподачі в інтернет-просторі (Чернобровкина, 2018; Шебанова \& Яблонська, 2019; Lea \& Spears, 2017; Suler, 2018; Vasalou \& Joinson, 2019). 3 іншого боку, постає проблема правильного сприйняття партнера по спілкуванню, який постає перед людиною винятково віртуально - через посередництво текстових повідомлень і графічних образів (Бугайова, 2008; Митина \& Войскунский, 2015, Шебанова \& Тавровецька, 2018). Недостатність інформації про реальні якості співрозмовника, наділення його бажаними уявними властивостями й достоїнствами, відсутність візуальної складової у спілкуванні роблять партнера привабливішим, дозволяють вибудовувати ідеальний образ, який, завдяки відповідності всім критеріям іншого учасника, здатний викликати широкий спектр почуттів - від зацікавленості до закоханості та глибоких емоцій. Усе це зумовлює актуальність вивчення психологічних аспектів онлайнового пошуку шлюбного партнера.

Мета статті - з'ясувати особливості соціодемографічного «портрета» осіб, які шукають партнера в інтернет-мережі.

\section{Завдання статті}

1. Описати організацію збору даних в онлайн-середовищі.

2. На основі аналізу анкетних даних користувачів про себе та свої очікування від потенційного партнера визначити особливості самопрезентації осіб, які шукають партнера в інтернет-мережі.

\section{Методи та методики дослідження}

Методичний інструментарій дослідження передбачав аналіз та узагальнення праць, присвячених вивченню вірту(C) Shebanova Vitaliia

DOI (article): https://doi.org/10.32626/2227-6246.2020-49.386-406 
ального дискурсу; контент-аналіз анкетних даних у контексті виявлення особливостей мовної самопрезентації користувачів, які шукають партнера в інтернет-мережі.

Збір даних для емпіричного дослідження проведено на сайті Love.ua. Це український сервіс нових знайомств i ефективного спілкування 3 елементами розваг. Аудиторія сайту складається з українців і українок віком 18-45 років. Цей ресурс був обраний як поле дослідження з таких причин:

1) він відображається на перших позиціях при пошуковому запиті, отже, привертає до себе увагу найбільшої кількості зацікавлених користувачів;

2) сайт позиціонує себе як ресурс «знайомств для шлюбу та серйозних стосунків в Україні», що відповідає предмету нашого дослідження (зауважимо, що метою користування сайтом у частини користувачів є відкрите надання сексуальних послуг, проте такі анкети нами не аналізувалися);

3) сторінки користувачів містять відкриту статистику онлайн-спілкування (товариськість, популярність, відкритість), а також статистику переглядів профілю, котра свідчить про ефективність самоподачі.

Етичний аспект доступу до особистої інформації користувачів ми врахували, оскільки всі дані анкет і фотографії розміщено у відкритому доступі. Для взаємодії та спілкування на сайті потрібно зареєструватися, але перегляд анкет доступний будь-якому користувачеві в мережі Інтернет.

Відбір сторінок для участі у дослідженні здійснено за допомогою фільтра. У першу чергу, були відібрані особи віком від 25 до 40 років (для нас цікаві дорослі люди зі сформованою особистістю та достатнім життєвим досвідом у сфері інтимних стосунків). Другий фільтр стосувався мети розміщення анкети на сайті. Із запропонованих варіантів ми обрали такі:

- шлюб, створення родини;

- кохання, романтичні стосунки;

(c) Shebanova Vitaliia

DOI (article): https://doi.org/10.32626/2227-6246.2020-49.386-406 
DOI: https://doi.org/10.32626/2227-6246.2020-49

- народження та виховання дітей.

Серед масиву відібраних анкет за вищеозначеними критеріями нами проаналізовано кожну третю (щоб уникнути впливу особистих переваг і симпатій дослідника). Завдяки цьому було сформовано вибірку, що налічувала 120 інтернет-сторінок на сайті знайомств (50 жіночих і 70 чоловічих профілів). Усі отримані емпіричні дані було проаналізовано окремо для вибірок чоловіків i жінок. Значущість різниці

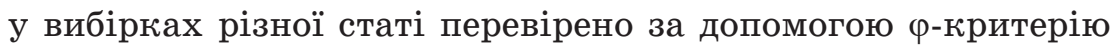
Фішера.

\section{Результати та дискусії}

Для створення власного привабливого образу користувач використовує готовий шаблон, представлений адміністрацією сайту знайомств, як єдиний спосіб реєстрації на сайті. Шаблон виконано у формі анкети із закритими відповідями, що відображаються на сторінці самопрезентації. Прагматична спрямованість сайту зумовлює зміст запитань анкети. Саме ці пункти, за задумом авторів, повинні найповніше розкрити особистість потенційного партнера по спілкуванню і стосунках за мінімальної витрати ресурсів. Користувач вільний обирати: відповідати або не відповідати на конкретні запитання, відображати правдиву інформацію чи будувати більш презентабельний образ, що допоможе досягти поставленої мети. Користувачеві достатньо обраного імені (паспортні дані вказувати не потрібно), на сторінці не повідомляється адреса електронної пошти, що передбачає спілкування винятково за допомогою сайту зі збереженням анонімності людини.

Отже, при створенні самопрезентації на сайті знайомств автор обмежений шаблоном, що регламентує його комунікативну поведінку, однак користувачеві надано відносну автономію творення власного образу.

Опишемо статистику відповідей на запитання реєстраційної анкети. Це дасть нам змогу змалювати актуальний (C) Shebanova Vitaliia

DOI (article): https://doi.org/10.32626/2227-6246.2020-49.386-406 
DOI: https://doi.org/10.32626/2227-6246.2020-49 2020. випуск 49

на даний час соціодемографічний «портрет» користувачів сайту знайомств.

1. Вік людини та вік бажаного партнера. Організовуючи вибіркове дослідження, ми обмежили вік комунікантів інтервалом 25-40 років, на який припадає не тільки найпродуктивніший репродуктивний період життя, але й досягнення особистісної зрілості та стабілізація професійної кар'єри. Саме у цей період пошук шлюбного партнера втрачає характер експериментування і становлення сексуальної ідентичності. Людина має достатній життєвий досвід (у тому числі й у стосунках із протилежною статтю) і більш-менш реалістичні уявлення як про себе, так і про бажаного супутника життя. У межах означеного життєвого періоду вік користувачів сайту знайомств представлено таким чином:

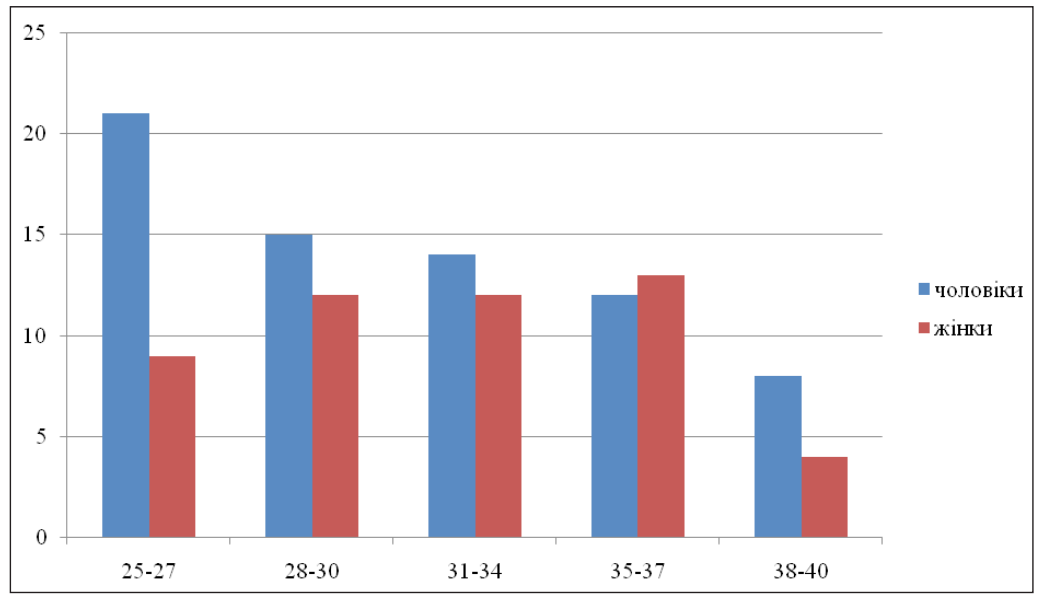

Puc. 1. Вік користувачів сайту знайомств (у межах періоду 25-40 років)

Із рис. 1 бачимо, що найактивніший сегмент користувачів сайту складають чоловіки у віці до 28 років. Відзначимо, що з віком їх активність пошуку партнера поступово спадає. Імовірно, це пояснюється тим, що на вік 25-27 років при-

(c) Shebanova Vitaliia

DOI (article): https://doi.org/10.32626/2227-6246.2020-49.386-406 
падає найактивніший пошук пари для стабільних стосунків. Відомо, що однією з особливостей сучасного демографічного розвитку європейських країн є те, що вік чоловіків і жінок при укладенні шлюбу поступово збільшується. Так, за даними Державної служби статистики України найбільша кількість чоловіків, які укладали шлюб у 1990 р., була у віковій групі 20-24 роки, у 2017 р. - 25-29 років. Відповідно, найбільша кількість жінок припадала у 1990 р. до 20 років, у 2000 р. - на 20-24 роки. Відзначимо, що такі тенденції i до сьогодні залишилися без змін (Державна служба статистики України, 2018). Зауважимо, що шлюбу передує достатньо тривалий період дошлюбних відносин, оптимальна тривалість якого складає від 1 до 3 років (Шнейдер, 2018). Отже, для більшості молодих чоловіків ситуація знайомства в Інтернеті фактично є продовженням реальної життєвої ситуації, розширенням її можливостей.

Серед жінок найбільша активність на сайті представлена у віковій групі 28-37 років. Ми пов'язуємо це із ситуацією, коли перший шлюб розірвано (більшість шлюбів в Україні реєструється у віці 20-24 років) або перші тривалі стосунки принесли розчарування. На нашу думку, саме у такому випадку жінка звертається до сайту знайомств як альтернативи (компенсації) реальної життєвої ситуації.

Зауважимо, що при обробці анкетних даних користувачів сайту знайомств ми виявили випадки недостовірної інформації про вік. Найчастіше це стосується молодих хлопців, які вказують нереальні завищені показники (порівняно з фотографією). Це означає, що підлітки та юнаки використовують сайт знайомств як «тренувальний майданчик», навчаючись залицянню і випробовуючи різні тактики поведінки щодо жінок. Такий спосіб знайомства дозволяє уникнути публічного приниження та соціального осуду, відповідно, є безпечнішим для самооцінки і самоприйняття.

На рис. 2, 3 презентовано графічне порівняння власного віку комунікантів і бажаного віку партнера. При цьому (c) Shebanova Vitaliia

DOI (article): https://doi.org/10.32626/2227-6246.2020-49.386-406 
DOI: https://doi.org/10.32626/2227-6246.2020-49 2020. випУСК 49

зазначимо, що ми виключили з розгляду анкети, у яких не вказаний вік бажаного партнера, а також анкети, у яких залишено стандартне формулювання віку «за умовчанням» (18-30 років).

Загалом, очікування чоловіків i жінок відповідають один одному .

Ж゚інки здебільшого шукають партнера, приблизно однакового за власним віком або старшого за віком. Як бачимо з рис. 2, нижня межа віку бажаного партнера переважно співпадає з віком самих жінок. Однак можна побачити цікаву тенденцію, що з віком у жінок діапазон вікової привабливості партнера розширюється.

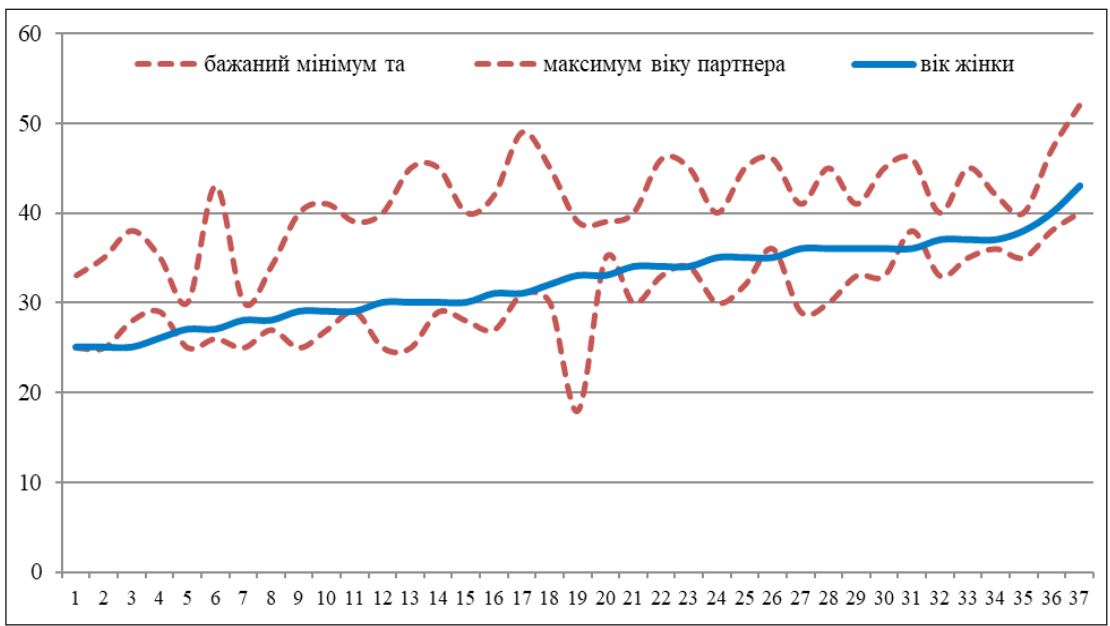

Puc. 2. Вік бажаного партнера в уявленнях жінок

Чоловіки загалом указують значно ширший віковий діапазон стосовно бажаного партнера, ніж жінки. Зокрема, $47 \%$ користувачів узагалі не вказують цієї інформації або залишають стандартне формулювання «18-30». 3 іншого боку, серед тих, хто вказав вік бажаної партнерки, переважають поціновувачі молодших жінок (рис. 3). Окрім того,

DOI (article): https://doi.org/10.32626/2227-6246.2020-49.386-406

(c) Shebanova Vitaliia 
як бачимо з рис. 3 , у чоловіків зі збільшенням віку ця тенденція стає все виразнішою.

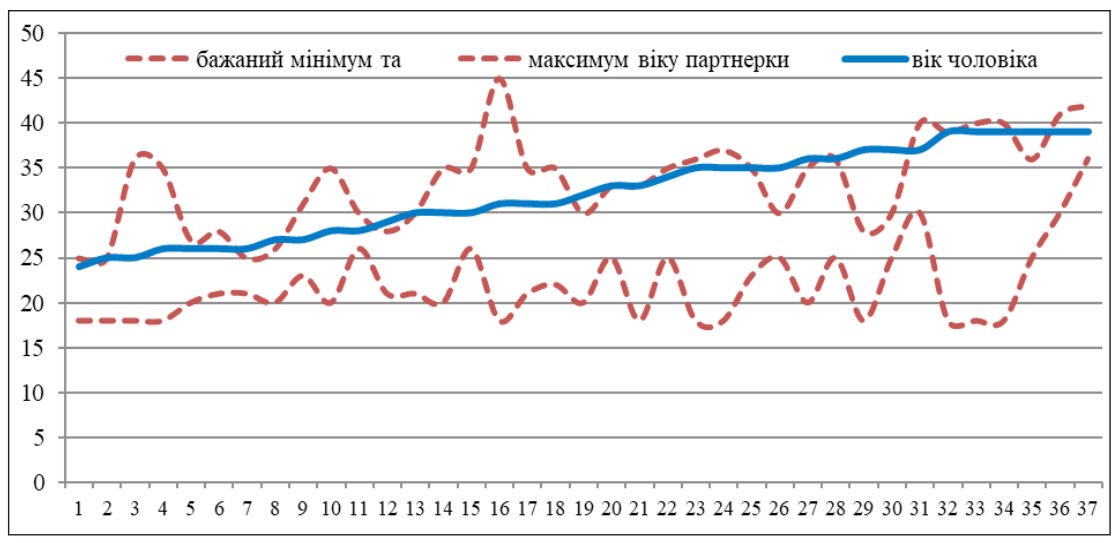

Puc. 3. Вік бажаної партнерки в уявленнях чоловіків

Ми пов'язуємо описану ситуацію перш за все з традиційним розподілом жіночих і чоловічих ролей у подружжі: чоловік у стосунках є головним, домінантним (що передбачає більший життєвий досвід і компетенцію, а, відповідно, й вік), а жінка - підлеглою, залежною та поступливою. I хоча патріархальні інститути шлюбу вже давно неактуальні, проте їх традиції залишилися у вигляді вікових очікувань щодо шлюбного партнера.

2. Місто, у яколу проживає людина. Розглянемо географію користувачів сайту знайомств. Безумовна перевага належить Києву - 34\% чоловіків і 44\% жінок зазначають його як місто проживання. Отже, темп і спосіб життя столиці сприяють залученню саме до онлайнової комунікації та знайомства. Значущо менше представлені великі міста-мільйонники - Харків, Одеса та Львів. 14,3\% чоловіків і 10\% жінок представляють малі міста й села. Наведена статистика не означає, що мешканцям невеликих населених пунктів важко знайти партнера саме у своєму місті (саме в цьому (C) Shebanova Vitaliia

DOI (article): https://doi.org/10.32626/2227-6246.2020-49.386-406 
випадку віртуальне знайомство найшвидше та найпростіше перевести в реальне спілкування). Поле пошуку на сайті надзвичайно широке - наприклад, відносно міста Херсона сервіс пропонує 485 анкет чоловіків і жінок.

Узагалі, за допомогою інтернет-мережі люди отримали можливість суттєво розширити географію пошуку партнера. Згадаємо, яку шалену затребуваність мали шлюби з іноземцями наприкінці 1990-х рр.

3. Сексуальна орієнтація. Цей пункт був включений до розгляду тому, що ми звернули увагу на досить значну кількість анкет, у яких у рубриці «шукаю» була вказана відповідь «хлопця або дівчину». Таких виявилося $22 \%$ серед жінок і $20 \%$ серед чоловіків. При детальнішому розгляді анкет ми помітили, що здебільшого у цих випадках метою спілкування серед інших указані дружні відносини, а також має місце досить поверхове інформаційне наповнення профілю (єдина фотографія, повна відсутність анкетних даних тощо). У випадку ретельнішої самопрезентації подібні анкети мали вказівку на гетеросексуальну орієнтацію респондентів. Отже, зазначений відсоток не можна вважати таким, що реально відображає розповсюдженість одностатевих зв'язків. Безумовно, це питання потребує уточнення та перевірки і є цікавою перспективою подальших досліджень.

4. Житлові улови, стосовно яких нас найбільше цікавив факт спільного проживання з батьками. Проблема встановлення близьких стосунків часто пов'язана з тим, що молода людина до періоду шлюбного віку не достатньою мірою звільнена від ролі «дитини» в батьківській родині. Тривалий період виховання дитини дозволяє краще і повніше підготувати її до життя, але одночасно фіксує, а то й просто стагнує дитячо-батьківські відносини. Ми поділяємо позицію Л. Б. Шнейдер, яка відзначає, що батьки можуть підготувати дитину до самостійного свідомого шлюбного вибору, а можуть і заплутати в сімейних зв'язках навіки (Шнейдер, 2018).

(c) Shebanova Vitaliia

DOI (article): https://doi.org/10.32626/2227-6246.2020-49.386-406 


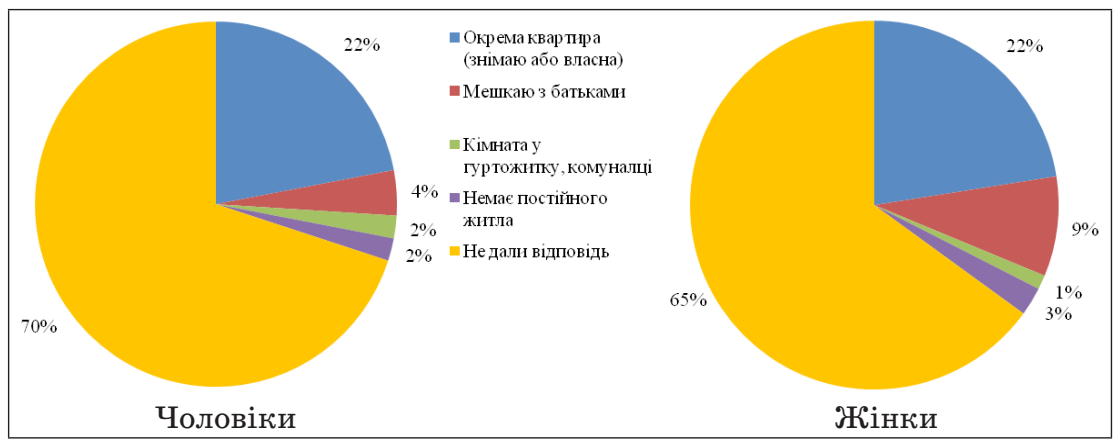

Puc. 4. Відповіді на анкету сайту знайомств щодо житлових умов

Як бачимо з рис. 4, користувачі сайту знайомств при пошуку партнера у більшості випадків приховують інформацію щодо власних житлових умов. Серед тих, хто надав ці відомості, однакова кількість чоловіків і жінок (по 22\%) мають окреме житло, 9\% чоловіків і $4 \%$ жінок мешкають разом із батьківською родиною.

5. Робота, освіma й дохід. Так само, як і в попередньому випадку, користувачі сайтів знайомств часто пропускають відповідь на запитання про власні статки. Серед тих, хто відповів на це запитання, переважають чоловіки та жінки зі стабільним середнім доходом (34\% і $32 \%$ відповідно). Жіінки порівняно частіше за чоловіків указують невеликий прибуток (18\% жінок, порівняно з 3\% чоловіків). Чоловіки частіше за жінок презентують себе як заможних (10\% і 4\% відповідно). Звичайно, критерії великого або невеликого заробітку багато в чому є суб'єктивними.

Як показав аналіз анкет, користувачі сайту знайомств зазвичай уникають відповідей на запитання, пов'язані з їх соціальним статусом і матеріальним становищем. Ми вважаємо, що у випадку серйозного ставлення до знайомства і пошуку відповідного для себе партнера, ця інформація є (c) Shebanova Vitaliia

DOI (article): https://doi.org/10.32626/2227-6246.2020-49.386-406 
DOI: https://doi.org/10.32626/2227-6246.2020-49 2020. ВИПУСК 49

необхідною. Адже вона стосується схожості соціального базису потенційних партнерів.

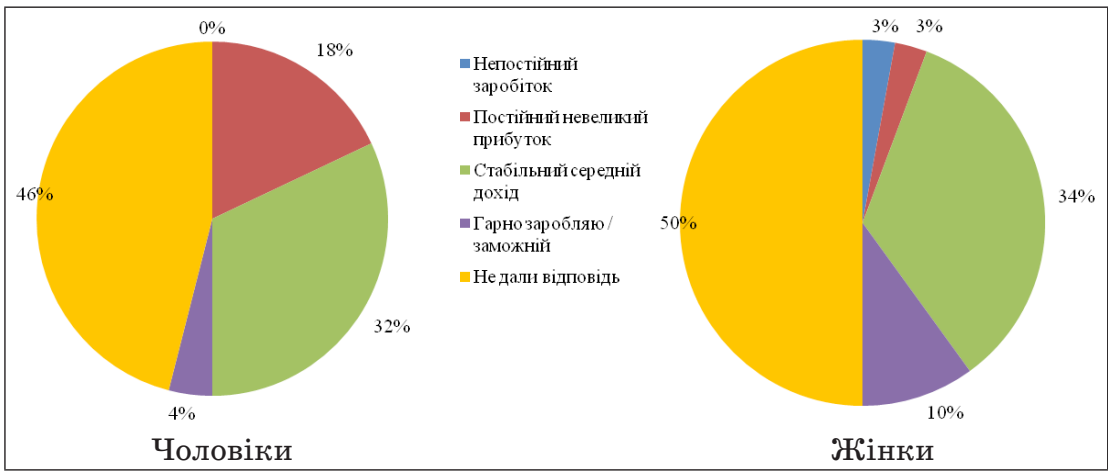

Puc. 5. Відповіді на запитання анкети сайту знайомств щодо рівня заробітку

Те ж саме стосується і рівня освіти комунікантів. Ця інформація також розкривається чоловіками 3 невеликою готовністю (рис. 6).

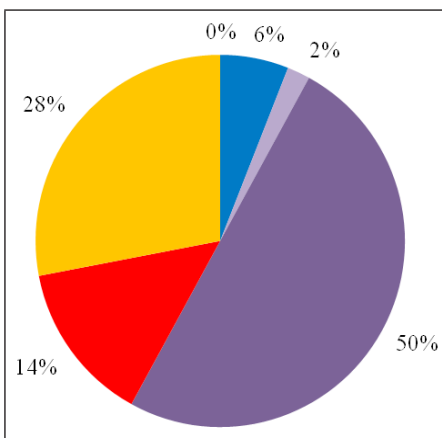

Чоловіки

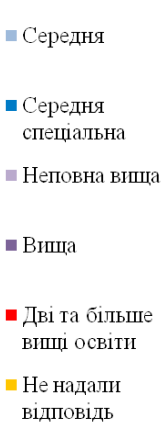

відповідь

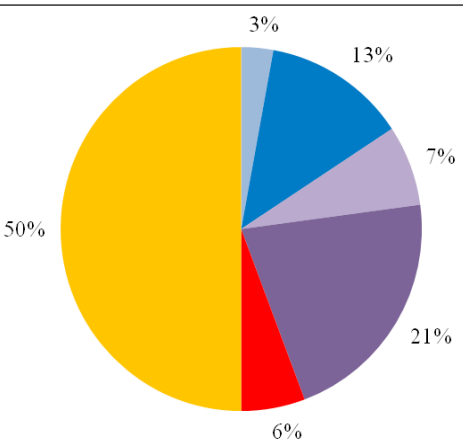

Жеінки

Puc. 6. Відповіді на запитання анкети щодо рівня освіти

Як бачимо, жінки на сайті знайомств значно рідше приховують (або вважають неважливою) інформацію щодо

(c) Shebanova Vitaliia

DOI (article): https://doi.org/10.32626/2227-6246.2020-49.386-406 
власної освіти, водночас мають набагато вищий рівень освіти, ніж чоловіки. Загалом 64\% користувачів-жінок мають вищу освіту або отримали їі декілька разів. Серед чоловіків відповідна група складає $27 \%$ ( $\varphi^{*}$ емп $=4,10$, різниця достовірна за $\mathrm{p} \leq 0,000$ ).

6. Наявність дітей $і$ ставлення до цього є важливим орієнтиром стосовно сімейного статусу партнера і можливості майбутніх сімейних відносин. Половина чоловіків не відповідають на запитання про наявність дітей, серед жінок таких $30 \%$. Приблизно однакова кількість представників обох статей не мають дітей (30\% чоловіків і $28 \%$ жінок) або вказують, що не мають, але б хотіли мати дитину (13\% і 14\% відповідно). 24\% жінок, зареєстрованих на сайті знайомств, мають дітей і мешкають разом із ними, що є типовою ситуацією при розлученні подружжя. Для матерів-одиначок, зайнятих роботою та вихованням дітей, сайт знайомств часто є найдоступнішою можливістю знову розпочати стосунки з чоловіком.

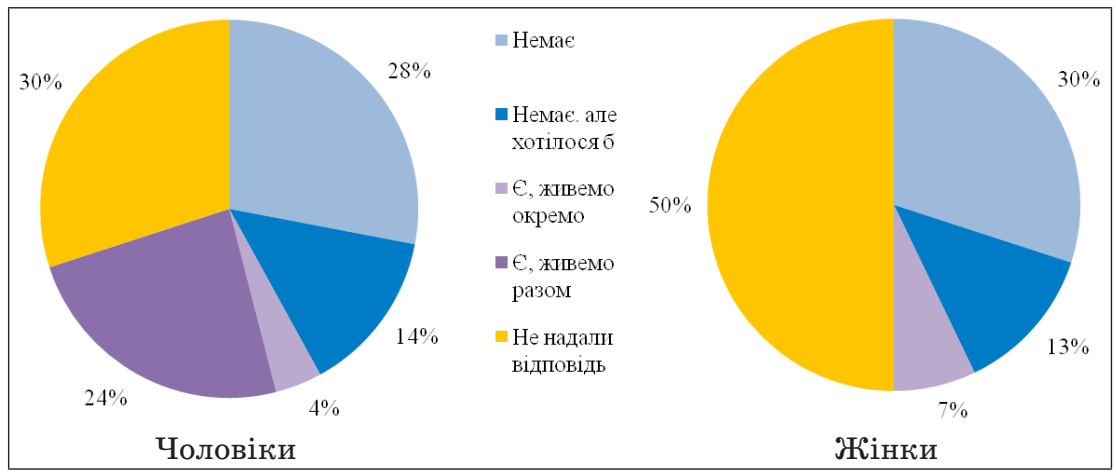

Puc. 7. Відповіді на запитання анкети щодо наявності дітей

7. Одне з головних і обов'язкових запитань анкети реєстрації на сайті стосується мети знайолства. Нагадаємо, що при відборі складу вибірки ми обрали анкети, у яких (C) Shebanova Vitaliia

DOI (article): https://doi.org/10.32626/2227-6246.2020-49.386-406 
DOI: https://doi.org/10.32626/2227-6246.2020-49 2020. випуск 49

зазначено такі цілі знайомства: шлюб, створення родини, кохання, романтичні стосунки, народження та виховання дітей. Проте користувачі зазвичай указують декілька цілей, статистику яких відображено на рис. 8.

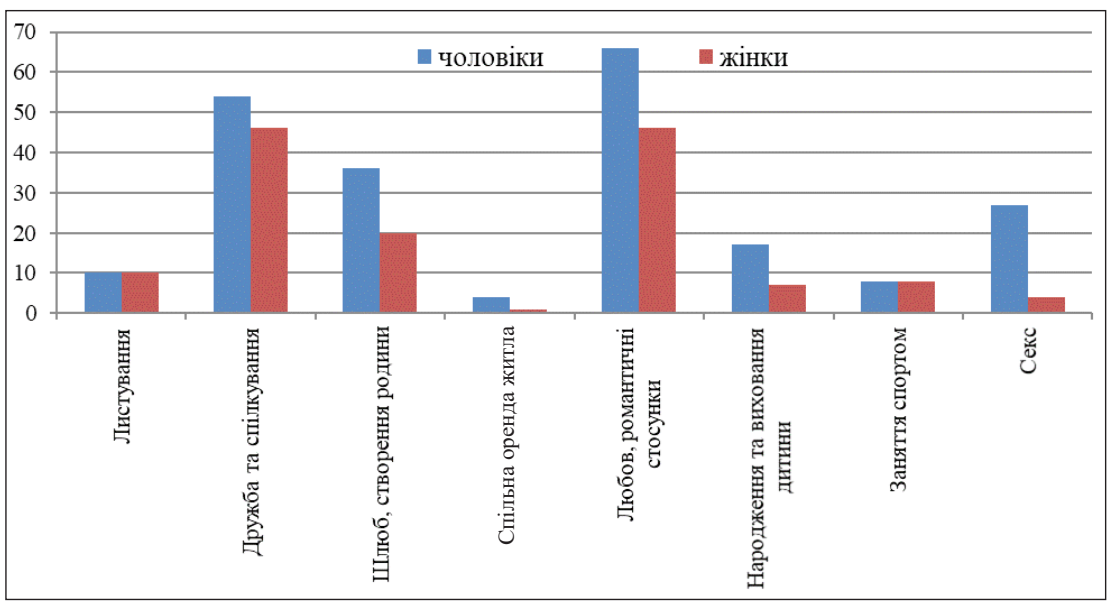

Puc. 8. Мета реєстрації анкети на сайті знайомств

Зазвичай, користувачі незалежно від статі вказують у цьому пункті два варіанти відповіді - дружнє спілкування та романтичні стосунки. Цю комбінацію можна вважати стандартною. Тому будь-які відхилення від неї є інформативними. Якщо користувач указує шлюб і народження дитини як мету знайомства, це дійсно означає, що він готовий до серйозних стосунків.

Із табл. 1 ми бачимо приблизно однаковий розподіл відповідей у представників чоловічої та жіночої статі, проте спостерігається певна різниця, значущість якої перевірено за допомогою $\varphi$-критерію Фішера. Чоловіки набагато більше зацікавлені у сексі й відверто заявляють про це (міжгрупова різниця достовірна за $\mathrm{p} \leq 0,000)$. ЖКінки достовірно частіше, ніж чоловіки, шукають у партнері дружніх стосунків і спілкування $(\mathrm{p} \leq 0,01)$.

(c) Shebanova Vitaliia

DOI (article): https://doi.org/10.32626/2227-6246.2020-49.386-406 
Мета спілкування на сайті знайомств у чоловіків і жінок

\begin{tabular}{|l|c|c|c|c|}
\hline & $\begin{array}{c}\text { Чоловіки } \\
\mathbf{( 7 0} \text { осіб) }\end{array}$ & $\begin{array}{c}\text { Жінки } \\
\text { (50 осіб) }\end{array}$ & & $\begin{array}{c}\text { Рівень } \\
\text { достовір- } \\
\text { ності }\end{array}$ \\
\hline Листування & $14,3 \%$ & $20 \%$ & 0,82 & - \\
\hline Дружба та спілкування & $77,1 \%$ & $92 \%$ & 2,29 & $\mathrm{p} \leq 0,011$ \\
\hline Шлюб, створення родини & $51,4 \%$ & $40 \%$ & 1,24 & - \\
\hline Спільна оренда житла & $5,7 \%$ & $2 \%$ & 1,07 & - \\
\hline $\begin{array}{l}\text { Любов, романтичні } \\
\text { стосунки }\end{array}$ & $94,3 \%$ & $92 \%$ & 0,49 & - \\
\hline $\begin{array}{l}\text { Народження та виховання } \\
\text { дитини }\end{array}$ & $24,3 \%$ & $14 \%$ & 1,42 & - \\
\hline Заняття спортом & $11,4 \%$ & $16 \%$ & 0,72 & - \\
\hline Секс & $38,6 \%$ & $8 \%$ & 4,14 & $\mathrm{p} \leq 0,000$ \\
\hline
\end{tabular}

Порівняння результатів нашого дослідження 3 іншими підтверджує факт, що більшість користувачів сайтів знайомств - це вільні чоловіки і жінки, без вищої освіти, із середнім доходом (Ухова, 2014; Чернобровкина, 2018).

\section{Висновки}

Виявлені статеві особливості у відповідях на запитання анкети сайту знайомств відображають реальні соціальнодемографічні тенденції в українському суспільстві.

Для більшості чоловіків ситуація знайомства в Інтернеті є продовженням реальної життєвої ситуації, розширенням їі можливостей. ЖЖінки здебільшого звертаються до сайту знайомств як до альтернативи (компенсації) реальної життєвої ситуації. Підлітки та юнаки використовують сайт як «тренувальний майданчик», навчаючись залицянню та випробовуючи різні тактики поведінки відносно осіб протилежної статі.

При створенні самопрезентації на сайті знайомств автор обмежений рамками шаблону (анкети), що регламентує ко(C) Shebanova Vitaliia

DOI (article): https://doi.org/10.32626/2227-6246.2020-49.386-406 
мунікативну поведінку, однак йому надано відносну автономію творення власного образу. Користувачі сайту зазвичай уникають відповідей на запитання, пов'язані з їх соціальним статусом, освітою і матеріальним становищем. Проте у випадку серйозного ставлення до знайомства ця інформація є необхідною, адже вона стосується схожості соціального базису майбутніх партнерів.

Проведене дослідження не вичерпує всіх аспектів проблеми. У наших наступних публікаціях ми зупинимося на аналізі текстової та графічної самопрезентації чоловіків і жінок для пошуку партнера.

Окрім того, вважаємо, що необхідно детально вивчити гендерні стереотипи, уявлення, установки, домінуючі в Інтернеті, з'ясувати їх вплив і взаємозв'язок з аналогами в реальному світі, а також виявити причини і прогнозування наслідків трансформацій, що відбуваються у цій галузі. Проте соціально-психологічні дослідження у цій сфері не встигають за стрімким розвитком інформаційного середовища. Процеси, що відбуваються в Інтернеті та під впливом Інтернету, вивчаються із запізненням на 3-5 років, але в ідеалі повинні випереджати і прогнозувати розвиток соціальних процесів.

\section{Література}

Бугайова Н. М. Віртуальні романтичні стосунки в інтернеті, кіберсексуальна залежність. URL : http://newlearning.org.ua/sites/default/ files/praci/zbirnyk-2008/3.htm.

Державна служба статистики України. Статистика шлюбного віку жінок та чоловіків по Україні в період з 1990-2018 роки URL : https:// dostup.pravda.com.ua/request/statistika_shliubiv_ta_rozluchie.

Мацюк В. В. Психологічні механізми формування у молоді образу майбутнього шлюбного партнера: автореф. дис. .... канд. психол. наук: 19.00.07. Кииї, 2019. 21 с.

Митина О. В., Войскунский А. Е. Интернет в гендерном измерении. Введение в гендерные исследования / под общ. ред. И. В. Костиковой. Москва : Аспект-Пресс, 2015. С. 204-216.

(c) Shebanova Vitaliia

DOI (article): https://doi.org/10.32626/2227-6246.2020-49.386-406 
Ухова Л. В. Социокультурный «портрет» потребителя брачной рекламы. Ярославский педагогический вестник. 2014. № 4. URL : https:// cyberleninka.ru/article/n/sotsiokulturnyy-portret-potrebitelyabrachnoy-reklamy.

Чернобровкина И. Г. Гендерные аспекты в анализе интернет-коммуникаций. Интегративный поход к психологии человека и соииальнолу взаилодействию людей: Материаль Х Всероссийской научно-практической конференции. Москва : СВИВТ, 2018. С. 155162.

Шебанова В., Тавровецька Н. Застосування інструментарію візуально-наративного підходу у психологічній допомозі особистості. Психолінгвістика. 2018. Вип. 24 (1). С. 381-402. URL : https:// doi.org/10.31470/2309-1797-2018-24-1-381-402.

Шебанова В., Яблонська Т., Нікнейм як засіб мовної самопрезентації в Інтернеті осіб з порушеннями харчової поведінки. Психолінгвістика. 2019. Вип. 25 (1). С. 409-430. URL : https://doi. org/10.31470/2309-1797-2019-25-1-409-430.

Шнейдер Л. Б. Психология семейных отношений. Москва : ЭКСМОПресc, 2018. 512 с.

Lea, M., \& Spears, R. (2017). Paralanguage and social perception in computer-mediated communication. Journal of Organizational Computing, 4, 321-341.

Suler, J. (2018). The Basic Psychological Features of Cyberspace Elements of a Cyberpsychology Model. The Psychology of Cyberspace, 8. URL : http://users.rider.edu/ suler/psycyber/psycyber.html.

Vasalou, A., \& Joinson, A. (2019). Me, myself and I: The role of interactional context on self-presentation through avatars. Computers in Human Behavior, 25, 510-520.

\section{References}

Buhaiova, N. M. (2008). Virtualni romantychni stosunky $v$ interneti, kiberseksualna zalezhnist [Virtual romantic relationships on the Internet, cybersexual addiction]. Retrieved from http://newlearning. org.ua/sites/default/files/praci/zbirnyk-2008/3.htm [in Ukrainian].

Derzhavna sluzhba statystyky Ukrainy (2018). Statystyka shliubnoho viku zhinok ta cholovikiv po Ukraini $v$ period z 1990-2018 roky [Statistics of marriage age of women and men in Ukraine in the period from 1990-2018]. Retrieved from https://dostup.pravda.com.ua/ request/statistika_shliubiv_ta_rozluchie [in Ukrainian].

Matsiuk, V. V. (2019). Psykholohichni mekhanizmy formuvannia u molodi obrazu maibutnioho shliubnoho partnera [Psychological mechanisms

(C) Shebanova Vitaliia

DOI (article): https://doi.org/10.32626/2227-6246.2020-49.386-406 
of formation in youth of the image of the future marriage partner]. Extended abstract of candidate's thesis. Kyiv [in Ukrainian].

Mitina, O. V., \& Voiskunskii, A. E. (2015). Internet v gendernom izmerenii [Internet in the gender dimension]. I. V. Kostikova (Ed.). Vvedeniie $v$ gendernyie issledovaniia - Introduction to gender studies, (pp. 204216). Moskva : Aspekt-Press [in Russian].

Ukhova, L. V. (2014). Sotsiokulturnyi «portret» potrebitelia brachnoi reklamy [Sociocultural "portrait» of the consumer of marriage advertising]. Yaroslavskii pedagogicheskii vestnik - Yaroslavl Pedagogical Bulletin, 4. Retrieved from https://cyberleninka.ru/article/n/ sotsiokulturnyy-portret-potrebitelya-brachnoy-reklamy [in Russian].

Chernobrovkina, I. G. (2018). Gendernyie aspekty v analize internet-kommunikatsii [Gender aspects in the analysis of Internet communications]. Integrativnyi podkhod $k$ psikhologii cheloveka $i$ sotsialnomu vaaimodeistviiu liudei - Integrative approach to human psychology and social interaction of people: Proceedings of the X All-Russian Scientific and Practical Conference, (pp. 155-162). Moskva : SVIVT [in Russian].

Shebanova, V., \& Tavrovetska, N. (2018). Zastosuvannia instrumentariiu vizualno-naratyvnoho pidkhodu u psykholohichnii dopomozi osobystosti [Application of the Instrumentarium of a Visual-Narrative Approach in Psychological Assistance to Personality]. Psycholinguistics. Psykholinhvistyka. Psikholingvistika - Psycholinguistics. Psycholinguistics. Psycholinguistics, 24 (1), 381-402. Retrieved from https:// doi.org/10.31470/2309-1797-2018-24-1-381-402 [in Ukrainian].

Shebanova, V., \& Yablonska, T. (2019). Nikneim yak zasib movnoi samoprezentatsii v Interneti osib z porushenniamy kharchovoi povedinky [Nickname as a means of linguistic self-presentation in the internet of people with eating disorders]. Psycholinguistics. Psykholinhvistyka. Psikholingvistika - Psycholinguistics. Psycholinguistics. Psycholinguistics, 25 (1), 409-430. Retrieved from https://doi. org/10.31470/2309-1797-2019-25-1-409-430 [in Ukrainian].

Shneider, L. B. (2018). Psikhologiia semeinykh otnoshenii [Psychology of family relations ]. Moskva : EKSMO-Press [in Russian].

Lea, M., \& Spears, R. (2017). Paralanguage and social perception in computer-mediated communication. Journal of Organization Computing, $4,321-341$.

Suler, J. (2018). The Basic Psychological Features of Cyberspace Elements of a Cyberpsychology Model. The Psychology of Cyberspace. Retrieved from http://users.rider.edu/ suler/psycyber/psycyber.html.

(C) Shebanova Vitaliia

DOI (article): https://doi.org/10.32626/2227-6246.2020-49.386-406 
DOI: https://doi.org/10.32626/2227-6246.2020-49 2020. ВиПУСК 49

Vasalou, A., \& Joinson, A. (2019). Me, myself and I: The role of interactional context on self-presentation through avatars. Computers in Human Behavior, 25, 510-520.

\section{Шебанова Віталія. Особливості соціодемографічного «портрета» осіб, які шукають шлюбного партнера в інтернет-мережі}

\section{АНОТАЦІЯ}

Mema cmammi - з'ясувати особливості соціодемографічного «портрета» осіб, які шукають шлюбного партнера в інтернет-мережі.

Методи дослідження. Методичний інструментарій дослідження передбачав аналіз та узагальнення праць, присвячених вивченню віртуального дискурсу осіб, які шукають шлюбного партнера в інтернет-мережі; контент-аналіз анкетних даних у контексті виявлення особливостей мовної самопрезентації користувачів, які шукають шлюбного партнера в інтернет-мережі. Збір даних для емпіричного дослідження здійснено на сайті Love.ua.

Вибірка дослідження налічувала 120 інтернет-сторінок на сайті знайомств (50 жіночих і 70 чоловічих профрілів). Усі отримані емпіричні дані було проаналізовано окремо для вибірок чоловіків і жінок. Значущість різниці обраховано за допомогою ч-критерію Фішера.

Результати дослідження дали змогу визначити особливості соціодемографрічного «портрета» осіб, які шукають шлюбного партнера в інтернет-мережі.

Висновок. Виявлені статеві особливості у відповідях на запитання анкети сайту знайомств відображають реальні соціально-демографічні тенденції в українському суспільстві.

3'ясовано, що для більшості чоловіків ситуація знайомства в Інтернеті є продовженням реальної життєвої ситуації, розширенням ії можливостей. Жінки здебільшого звертаються до сайту знайомств як до альтернативи (компенсації) реальної життєвої ситуації. Підлітки та юнаки використовують сайт як «тренувальний майданчик», навчаючись залицянню та випробовуючи різні тактики поведінки відносно осіб протилежної статі.

Досліджено, що при створенні самопрезентації на сайті знайомств автор обмежений рамками шаблону (анкети), що регламентує комунікативну поведінку, однак йому надано відносну автономію творення (C) Shebanova Vitaliia

DOI (article): https://doi.org/10.32626/2227-6246.2020-49.386-406 http://journals.uran.ua/index.php/2227-6246 
DOI: https://doi.org/10.32626/2227-6246.2020-49 2020. випУСК 49

власного образу. Користувачі сайту зазвичай уникають відповідей на запитання, пов'язані з їх соціальним статусом, освітою і матеріальним становищем. Проте у випадку серйозного ставлення до знайомства ия інформація є необхідною, адже вона стосується схожості соціального базису майбутніх партнерів.

Ключові слова: інтернет-комунікація, мовна самопрезентація особистості, аналіз анкетних даних, знайомства в Інтернеті, пошук партнера.

Шебанова Виталия. Особенности социодемографического «портрета» лии, ищущих брачного партнера в интернет-сети

\section{АННОТАЦИЯ}

Цель статьи - выяснить особенности социодемографического «портрета» лии, ищущих брачного партнера в интернет-сети.

Методы исследования. Методический инструментарий исследования предусматривал анализ и обобщение работ, посвященных изучению виртуального дискурса лии, ищущих брачного партнера в сети Интернет; контент-анализ личных данных в контексте выявления особенностей языковой самопрезентации пользователей, которые ищут брачного партнера в интернет-сети. Сбор данных для эмпирического исследования осуществлено на сайте Love.ua. Выборка исследования насчитывала 120 интернет-страниц на сайте знакомств (50 женских и 70 мужских профилей). Все полученные эмпирические данные были проанализированы отдельно для выборок мужчин и женщин. Статистическая значимость установлена с помощью $\varphi$-критерия Фишера.

Результаты исследования позволили определить особенности социодемографического "портрета» лии, ищущих брачного партнера в интернет-сети.

Вывод. Выявленные половые отличия в ответах на вопросы анкеты сайта знакомств отображают реальные социально-демографические тенденции в украинском обществе.

Установлено, что для большинства мужчин ситуация знакомства в Интернете является продолжением реальной жизненной ситуации, расширением ее возможностей. Женщины в основном обращаются к сайту знакомств как к альтернативе (компенсации) реальной жизненной ситуации. Подростки и юноши используют сайт как «тренировочную пло-

(c) Shebanova Vitaliia

DOI (article): https://doi.org/10.32626/2227-6246.2020-49.386-406 
DOI: https://doi.org/10.32626/2227-6246.2020-49

щадку», учатся ухаживать и проявлять различные тактики поведения в отношении лиц противоположного пола.

Доказано, что при создании самопрезентации на сайте знакомств автор ограничен рамками шаблона (анкеты), регламентирующего коммуникативное поведение, однако ему предоставлена относительная автономия создания собственного образа. Пользователи сайта обычно избегают ответов на вопросы, связанные с их социальным статусом, образованием и материальным положением. Однако в случае серьезного отношения к знакомству эта информация необходима, ведь она касается сходства социального базиса будущих партнеров.

Ключевые слова: интернет-коммуникация, языковая самопрезентация личности, анализ анкетных данных, знакомства в Интернете, поиск партнера.

Original manuscript received April 30, 2020

Revised manuscript accepted June 02, 2020 